\title{
Molecular evolution of human species D adenoviruses
}

\author{
Christopher M. Robinson ${ }^{\mathrm{a}, \mathrm{d}}$, Donald Seto ${ }^{\mathrm{b}}$, Morris S. Jones ${ }^{\mathrm{c}}$, David W. Dyer ${ }^{\mathrm{d}}$, and James \\ Chodosh ${ }^{\mathrm{a},{ }^{*}}$ \\ aHowe Laboratory, Massachusetts Eye and Ear Infirmary, Department of Ophthalmology, Harvard \\ Medical School, 243 Charles Street, Boston, Massachusetts, 02114, USA \\ bDepartment of Bioinformatics and Computational Biology, School of Systems Biology, George \\ Mason University. 10900 University Blvd., MSN 5B3, Manassas, VA, 20110, USA \\ 'Viral and Rickettsial Disease Laboratory, California Department of Public Health. Richmond, \\ California, 94804 USA \\ dDepartment of Microbiology and Immunology, University of Oklahoma Health Sciences Center, \\ 975 N.E. $10^{\text {th }}$, Oklahoma City, Oklahoma, 73104, USA
}

\begin{abstract}
Adenoviruses are medium-sized double stranded DNA viruses that infect vertebrates. Human adenoviruses cause an array of diseases. Currently there are 56 human adenovirus types recognized and characterized within seven species (A-G). Of those types, a majority belongs to species D. In this review, the genomic conservation and diversity are examined amongst human adenoviruses within species D, particularly in contrast to other human adenovirus species. Specifically, homologous recombination is presented as a driving force for the molecular evolution of human adenoviruses and the emergence of new adenovirus pathogens.
\end{abstract}

\section{Keywords}

human adenovirus; HAdV-D; Recombination

\section{Introduction}

The first human adenovirus (HAdV) was isolated in 1953 from human adenoids and characterized independently by two groups (Hilleman and Werner, 1954; Rowe et al., 1953). HAdV infections are now recognized as a significant source of human morbidity and mortality, and affect patients world-wide and across all age groups. HAdV infections are readily transmittable and, in some cases, highly contagious. HAdVs infect multiple mucosal sites, including the gastrointestinal, respiratory, genitourinary, and ocular surfaces (Table 1) (Arnold et al., 2010; Chu and Pavan-Langston, 1979; Dingle and Langmuir, 1968; Wood, 1988). HAdVs have also been associated with obesity (Atkinson et al., 2005; Dhurandhar et al., 2000). Thus, HAdVs are major human pathogens that have a range of effects upon their host. In addition, HAdV infections can be particularly serious in immunocompromised

(C) 2011 Elsevier B.V. All rights reserved.

*Corresponding author. Mailing address: Massachusetts Eye and Ear Infirmary, 243 Charles Street, Boston, MA, 02114. Phone: (617) 573-6398. Fax: (617) 573-4324.james_chodosh@meei.harvard.edu.

Publisher's Disclaimer: This is a PDF file of an unedited manuscript that has been accepted for publication. As a service to our customers we are providing this early version of the manuscript. The manuscript will undergo copyediting, typesetting, and review of the resulting proof before it is published in its final citable form. Please note that during the production process errors may be discovered which could affect the content, and all legal disclaimers that apply to the journal pertain. 
individuals (Kojaoghlanian et al., 2003), including transplantation patients. HAdVs have been extensively studied for use in gene therapy applications for a variety of diseases (Boulay et al., 2000; Crystal et al., 1994; Cypel et al., 2009; Hedman et al., 2003; Jager and Ehrhardt, 2007; Lippin et al., 2005; Stewart et al., 1999; van der Linden et al., 2005). In light of their potential use as therapeutic vectors in human patients, understanding the evolution and relationships of HAdVs is particularly critical. In this review, the current state-of-the-art in HAdV genomics is discussed, with a specific focus on HAdV species D (HAdV-D), the molecular evolution of HAdV via homologous recombination, and the emergence of new HAdV pathogens.

\section{Adenovirus structure and phylogeny}

\subsection{Structure of HAdVs}

Adenoviruses are non-enveloped viruses with a linear double stranded DNA genome that ranges from 26 to $45 \mathrm{~kb}$. The icosahedral shaped capsid ranges in diameter from 70 to 100 nanometers, and consists of three major proteins (hexon, penton base, and fiber) and numerous minor capsid proteins. The hexon is the major constituent of the capsid, comprising 240 capsomers to form 20 triangular surfaces. Five penton base proteins form each penton capsomer at 12 vertices, where the penton capsomer supports an extending trimeric fiber protein. The fiber protein varies in size based on the particular HAdV type (Chroboczek et al., 1995). Of the fiber protein, the distal fiber knob domain binds the virus to its primary host cell receptor (Arnberg et al., 2002; Bergelson et al., 1997; Nilsson et al., 2011; Wu et al., 2004). Minor capsid proteins, IIIa, VI, VIII, and IX, provide stability for the mature virion and have been implicated in downstream events post-viral internalization (Smith et al., 2010; Wiethoff et al., 2005). The core of the capsid comprises four additional proteins (V, VII, X, and the terminal protein) that interact with the viral DNA. Multiple copies of the adenoviral protease are also found within the mature virion.

\subsection{Human adenovirus phylogeny}

The Adenoviridae family of viruses is divided into five genera: Atadenovirus, Siadenovirus, Mastadenovirus Aviadenovirus and Ichtadenovirus These divisions are based on the host species and the composition of the DNA (Davison et al., 2003). HAdVs are classified within the genus Mastadenovirus, with 56 types characterized to date, and classified into 7 species (A-G) on the basis of serology and genome analysis (Fig. 1A). Seven simian adenoviruses also have been classified within human adenovirus taxonomy (HAdV-B, E and G species), based on close sequence identity to their human counterparts. The number of known HAdV types is steadily increasing as high-throughput sequencing increasingly allows for the rapid, relatively inexpensive and comprehensive whole genome analysis of new HAdV isolates.

\section{Human adenovirus genomic organization and genetic diversity}

\subsection{Structure of HAdV genomes}

All HAdV genomes share a similar organization. The HAdV genome is divided into early, intermediate, and late regions, which correspond to the infectious cycle of the virus and reflect the transcription patterns (Fig. 1B). The early region of the genome consists of four families of transcripts (E1, E2, E3 and E4) that are needed for the establishment of viral replication. The intermediate genes consist of two transcripts (IX and IVa2) and the late region of the genome contains five families of transcripts (L1, L2, L3, L4 and L5) that are involved in the production of mature virions. The genomes also contain inverted terminal repeat (ITR) regions located at each 5' and 3' end, which serve as origins of replication for the virus and contain conserved sequenced motifs. Additionally, one or two RNA genes are encoded in the genome. 


\subsection{Genetic diversity of HAdV-D}

HAdV-D represents the largest class of HAdV species accounting for 35 out of the 56 recognized types, and is therefore the species most amenable to the study of adenoviral evolution. The first HAdV-D type to be classified was HAdV-D8, a major etiologic agent of epidemic keratoconjunctivitis (Jawetz et al., 1955). HAdV-D types have been isolated from the upper and lower respiratory, gastrointestinal, and genitourinary tracts, and the eye (Bell et al., 1959; de Jong et al., 1981; Hierholzer et al., 1982; Phillips et al., 1982; Rosen et al., 1961; Swenson et al., 1995). Eight types (D43-D49 and D51) were initially characterized after being isolated from AIDS patients, suggesting a possible role for the immunocompromised host in the genesis of new adenoviruses (De Jong et al., 1999; Hierholzer et al., 1988b; Schnurr and Dondero, 1993).

Currently 16 of the prototype HAdV-D genomes have been completely sequenced (HAdVD17 appears to be incomplete), while whole genome sequencing of the remaining 19, including HAdV-D17, are near completion (unpublished results). Analysis of all whole HAdV-D genomes available in GenBank has revealed an overall sequence identity of approximately 94\% (Fig. 2A) (Robinson et al., 2009a; Robinson et al., 2008; Robinson et al., 2009b). The areas of greatest diversity, i.e., those that account for most of the $6 \%$ difference in genome sequence identity, include the penton, hexon, and fiber open reading frames (ORFs), and the E3 region.

In contrast to identity within species $\mathrm{D}$, interspecies global sequence comparisons reveal sequence identities on average of 76\% (Fig. 2B). For species other than HAdV-D, intraspecies sequence comparisons reveal other areas of diversity (Fig. 2C-H). For example, studies of HAdV-A and HAdV-F types revealed an overall sequence identity of approximately $84 \%$ and $86 \%$, respectively, representing a higher degree of divergence within each species across the entire genome (Fig. 2C and G). HAdV-B genomes show a similar variability at the nucleotide level in the penton, hexon, and fiber genes, but less diversity in the E3 coding region (Fig. 2D). HAdV-C and HAdV-E genomes show diversity in the hexon, E3, and fiber ORFs, but have similar penton base genes (Fig. 2E).

3.2.1. HAdV-D E3 transcription unit-The E3 transcription unit encodes proteins that modulate the host immune response. While labeled as an "early" transcription region, transcripts from this gene family are actually expressed both early and late during viral infection (Bhat and Wold, 1986; Chow and Broker, 1978; Chow et al., 1979; Chow et al., 1980; Chow et al., 1977b). The E3 transcription unit represents an area of major divergence between HAdV-D and other HAdV species (Fig. 3) (Burgert and Blusch, 2000; Robinson et al., 2008; Robinson et al., 2009b); for example, the number of ORFs located within this region differs among HAdV species. The HAdV-D E3 region includes eight ORFs encompassing approximately 5000 nucleotides. Three of these (RID- $\alpha$, RID- $\beta$ and $14.7 \mathrm{~K}$ ) are conserved across every species of HAdV, and their gene products block apoptosis by the down-regulation of FAS, TRAIL 1 and TRAIL 2 receptors and the blockade of TNF- $\alpha$ (Benedict et al., 2001; Hilgendorf et al., 2003). One ORF (12.5K) is conserved in all species of HAdV except HAdV-F, but the function of the protein product from this gene is unknown (Hawkins and Wold, 1992). Two ORFs (CR1- $\alpha$ and CR1- $\beta$ ) have homologues in most HAdV species but also have no known function (Burgert and Blusch, 2000). The ORF for 19K (also noted as glycoprotein (gp) 19K) encodes a protein known to block MHC class Iassociated antigen presentation on the cell surface (Burgert et al., 1987; Deryckere and Burgert, 1996; Feuerbach et al., 1994). This has homologues in HAdV-B, -C, -D, and -E species members. An ORF corresponding to CR $1-\gamma$ in HAdV-D has only one apparent homolog corresponding to CR1- $\delta$ in HAdV-E genomes, but its function has not been 
determined (Li and Wold, 2000). The CR1- $\beta$ gene in the HAdV-D genomes appears to be unique to HAdV-D.

The known functions for confirmed E3 gene products all appear to involve immune evasion. Divergence between E3 regions of different HAdV species is striking, and is consistent with a theory of adenoviral evolution in which newer species evolve through the addition of protein coding potential within the E3 region (Fig. 3B and 3C). Whole genome phylogenetic trees also correlate well with the size of each E3 transcription unit, and similarly segregate by species. This analysis suggests that HAdV may have added immunomodulatory functions to successive HAdV species in order to evade immune pressure by a concurrently evolving host.

\section{Molecular evolution of HAdV-D through homologous recombination}

Homologous recombination among adenoviruses in vitro has been a well-known observation dating back to the 1970's where it was first described using temperature-sensitive and tumorigenic adenoviruses (Takemori, 1972; Williams et al., 1971; Williams and Ustacelebi, 1971). Recombinant adenoviruses were detected between genetic crosses of temperaturesensitive mutants of HAdV-C5 and a non-defective HAdV-C2/SV40 hybrid (Ad2 ${ }^{+} \mathrm{ND} 1$ ) which allowed mapping of crossover points, via restriction enzyme digests, between the individual recombinants and their parental viruses (Grodzicker et al., 1975; Mautner et al., 1975; Sambrook et al., 1975; Williams et al., 1975a). Coinfection of adenoviruses in vitro produces the highest percentage of recombinants between 36 and 54 hours post infection and is consistent with the replication cycle of the virus, with a range in recombination frequencies reported between $0.1 \%$ to $25 \%$ (Meinschad and Winnacker, 1980; Young and Silverstein, 1980). Homologous recombination appears to occur only between HAdV types within the same species and in regions of high sequence homology (Boursnell and Mautner, 1981; Williams et al., 1975b). Experiments that blocked DNA replication also delayed recombination, suggesting that DNA replication and recombination are intimately associated (Young et al., 1984). While homologous recombination has been proposed as the main mechanism for the evolution of HAdV types, illegitimate recombination has also been proposed as a mechanism, particularly in the hexon hypervariable regions (Crawford-Miksza et al., 1999).

With recent applications of whole genome sequencing and bioinformatics analysis, recombination has been described in HAdV-A, B, and D genomes (Lukashev et al., 2008; Robinson et al., 2009a; Robinson et al., 2011; Walsh et al., 2009), particularly in the penton base, hexon and fiber genes. However, since the nucleotide identity within other regions for each HAdV species is relatively high, recombination events in other parts of the genome might be missed by currently available software algorithms.

\subsection{HAdV-D penton base recombination}

Following the primary interaction of the virus fiber knob and a cellular receptor, the penton base serves as a site of the secondary interaction with the host target cell. An Arg-Gly-Asp (RGD) motif located on an outer loop of the penton base interacts with host cellular integrins $\alpha_{\mathrm{v}} \beta_{1}, \alpha_{\mathrm{v}} \beta_{3}$, and $\alpha_{\mathrm{v}} \beta_{5}$, leading in turn to viral internalization by endocytosis ( $\mathrm{Li}$ et al., 2001; Wickham et al., 1993). All known human adenoviruses have the RGD motif except for both members of species F, HAdV-F40 and HAdV-F41. The penton base coding region is a major site of diversity between HAdV genomes (Madisch et al., 2007; Robinson et al., 2009a; Robinson et al., 2008), and was recently identified as an area of homologous recombination within HAdV-D, centered around the two hyper-variable loops (HVL1 and the RGD loop) (Fig. 4A) (Madisch et al., 2007; Robinson et al., 2009a). X-ray crystallographic and structural studies have identified the hypervariable and RGD loops on 
the external surface of the viral capsid (Stewart et al., 1997; Zubieta et al., 2005). While the RGD loop has a clearly defined function, a similar function for the HVL1 has not been identified.

\subsection{HAdV-D hexon recombination}

The hexon protein is the major constituent of the viral capsid. It contains two hypervariable loops (L1 and L2) that appear to determine serologic reactivity (Crawford-Miksza and Schnurr, 1996; Toogood et al., 1992) and together form the serum neutralization epitope $\varepsilon$. This region is critical for the development of adenovirus vaccines (Lasaro and Ertl, 2009). The hexon protein also contains a region downstream of the hypervariable loops that is highly conserved among HAdV types.

Homologous recombination has also been identified and is common in the HAdV-D hexon gene (Fig. 4B), centered around the $\varepsilon$ determinant (Walsh et al., 2009; Walsh et al., 2010). Therefore, serotyping alone can create confusion in the characterization of strains.For example, HAdV-D15 and D29 have near identical hexon genes and cannot be reliably differentiated by serum neutralization alone or by DNA sequencing of hexon hypervariable regions (Hierholzer et al., 1991; Lu and Erdman, 2006; Rosen et al., 1962; Stevens et al., 1967; Wigand, 1987; Wigand et al., 1982). An example of misleading serotype can be found in HAdV-B, in particular, the respiratory pathogen HAdV-B55 (Walsh et al., 2010). Initially this virus was characterized as a HAdV-B11 strain based on its serology. However, respiratory disease is uncommonly associated with infection by HAdV-B11 (a renal pathogen), and HAdV-B55 caused severe acute respiratory disease. Complete genome sequence analysis revealed the hexon gene was indeed identical to that of HAdV-B11, but the remainder of the genome was identical to HAdV-B14, a known and serious respiratory pathogen. HAdV-B55 would appear to the host humoral immune system as HAdV-B11, and therefore would escape herd immunity to HAdV-B14 while retaining its respiratory tropism and pathogenicity.

\subsection{HAdV-D fiber recombination}

The adenovirus fiber gene has been well characterized in almost all HAdVs. Historically, the fiber protein allowed partial type identification through a hemagglutination inhibition test, and when combined with serum neutralization provides a much more complete identification than either method alone (Wigand, 1987). Three fiber monomers form the trimeric fiber protein which projects from the twelve vertices of the capsid. The protein contains three structural domains; tail, shaft and knob. The tail domain binds to the penton base capsomer at the proximal surface of each of 12 vertices of the capsid. A shaft domain, varying in length between HAdV types, results in the variable flexibility of fiber and subsequent differences between the ease of interaction between capsid penton base RGD and host cell integrins (Chiu et al., 2001; Wu et al., 2003). The fiber knob, located on the distal Cterminal end of the protein, binds to the primary host cellular receptor. Many HAdV-D types bind to the classical adenovirus receptor, coxsackie adenovirus receptor (CAR), but types HAdV-D8, D19, and D37, all associated with epidemic keratoconjunctivitis, appear to bind to CD46 and/or GD1a glycan (Arnberg et al., 2000; Nilsson et al., 2011; Wu et al., 2004). Recently, recombination was proposed to occur at the shaft/knob boundary, (Darr et al., 2009) (Fig. 4C). Recombination at this specific site does not appear to be a widespread, but recombination of the entire fiber gene is apparently common among HAdV-D types (for example, Figure 4D). 


\section{Newly identified HAdV pathogens}

Newly identified adenoviral pathogens representing apparently novel types appear to arise at least in part from recombination between two or more viruses, and can lead to human infections not previously associated with their parental strains (Robinson et al., 2009a; Walsh et al., 2009; Walsh et al., 2010). These viruses would have escaped correct characterization without whole genome sequencing and comprehensive recombination analysis. The gastroenteritis isolate HAdV-G52 was identified in 2007, and was the first novel HAdV identified in over a decade (Jones et al., 2007). This virus was characterized by whole genome sequencing and bioinformatics. The highly contagious corneal pathogen, HAdV-D53, was first characterized as a putative recombinant virus because its imputed serotype, using DNA sequencing, was consistent with HAdV-D22, whereas its fiber gene was similar to HAdV-D8 (Engelmann et al., 2006). Interestingly, HAdV-D22 is not an ocular pathogen. However, subsequent whole genome sequencing, bioinformatics, and a detailed in vivo infection analysis identified this virus as the product of recombination between HAdV-D37, D22, D8 and a fourth still unknown virus, with newly conferred corneal tropism (Walsh et al., 2009). HAdV-D53 was the first of three newly identified viruses associated with epidemic keratoconjunctivitis to be identified in the last few years, HAdV-D53, D54 and D56. Each was characterized by whole genome sequencing (Ishiko et al., 2008; Kaneko et al., 2009; Robinson et al., 2011; Walsh et al., 2009). These viruses have been detected in multiple countries suggesting they are important, emerging ocular pathogens (Aoki et al., 2008; Engelmann et al., 2006; Henquell et al., 2009; Kaneko et al., 2010). It should be noted that at present there is no way to be certain whether they emerged recently or were just undetected until now (Aoki et al., 2008; Ishiko et al., 2008; Kaneko et al., 2011). The other recently identified human adenovirus, HAdV-B55, is described above.

Co-infection between at least two adenoviruses with highly similar nucleotide sequence at recombination hotspots in the genome, and long-term presence in the gastrointestinal, respiratory, and/or genitourinary tracts (Fox et al., 1977; Garnett et al., 2002; Horvath et al., 1986; Horwitz et al., 1984; Macek et al., 1994; Marin et al., 2000; Vora et al., 2006) are likely prerequisites for successful recombination and emergence of new adenoviruses. HAdVs can be excreted and detected in the stool for weeks to months after initial infection (Curlin et al., 2010). Immunosuppression associated with HIV infection or other causes probably contributes to long-term viral persistence in affected patients, and creates a climate conducive to co-infection, thus explaining why so many adenoviruses identified in the last three decades have been isolated from AIDS patients.

Previous to the era of whole genome sequencing, serology was the principal means used to identify adenovirus types; hence the term serotype was applied to the first 51 HAdVs. The two types of serologic tests, serum neutralization, which tests humoral immunity to the hexon hypervariable loops, and hemagglutination inhibition, which identifies the fiber protein, are limited in their capacity to identify new clinical adenovirus isolates. Currently these are often substituted for by DNA sequencing of the epitopes, which it should be noted may not give identical results. Historically, serologic methods were enhanced greatly by DNA restriction enzyme analysis, which can identify a genotype as being different but cannot be relied upon to identify the uniqueness or the specific characteristics of the viral genome. Limited DNA sequencing of the hexon and fiber genes does not replace serology, but can be used to impute a likely serotype, that is, when the nucleotide sequences forming the $\varepsilon$ determinant are identical to those of a known serotype, the serotype is reasonably certain. However, it is not clear to what extent near sequence identity can be used to predict the results of serologic tests. Serology can suggest possible recombinant viruses in the natural population; so-called "intermediate" or "intertypic" strains are identified when the two principal serological tests provide contradictory results, seeming to indicate two 
different HAdV types (Adrian et al., 1985; Adrian and Wigand, 1986; Adrian et al., 1987; Hierholzer et al., 1988a; Hierholzer et al., 1980; Kajon et al., 2010; Kim et al., 1985; Matumoto et al., 1958; Norby, 1968; Parks et al., 1967; Wigand, 1987; Wigand and Fliedner, 1968). As these terms imply a ,temporary' state, they should be replaced with "putative recombinant".

Conflicting results between serum neutralization and hemagglutination inhibition may indicate a recombination event but cannot completely characterize the newly identified virus. While serologic methods are still used by clinicians and epidemiologists trying to quickly identify a given adenovirus in a population, and are important clinically in the development and application of adenovirus vaccines (Lasaro and Ertl, 2009; Top et al., 1971a; Top et al., 1971b), serological assays do not always reliably predict virus specific antibodies, for example to adenoviral vaccine vectors in vivo (Pichla-Gollon et al., 2009). When one considers the lack of available serum for every known HAdV type, cross reactivity between select types, and the existence of recombinant types relative to their prototype parental strains, it is clear that serologic tests have significant limitations in comparison to whole genome sequencing. Serologic determinants represent less than 5-6\% of the total genome, and in the age of genomics, serology used in isolation must be considered inadequate to fully characterize new HAdVs. Given the increasing wide availability and relatively low expense of DNA sequencing, sequencing has now essentially replaced serology in many laboratories, particularly for identification and characterization of new HAdVs within species D. A recent letter to the Journal of Virology suggested whole genome sequencing and phlyogenetic analysis should form the basis of characterizing new types. (Seto et al., 2011). To the contemporary adenovirologist, the DNA sequence and its analysis by bioinformatic methods are preeminent in the recognition and naming of types.

\section{Conclusions and perspectives}

Since their first identification in 1953, adenoviruses have come to be known as a significant source of morbidity and mortality in the human population. Human adenoviruses also present a great tool and a model system to study molecular and cell biology. For example, RNA splicing was first described (Berget et al., 1977; Chow et al., 1977a), and a mechanism for viral induction of cancer was first proposed, using HAdVs (Whyte et al., 1988). Also, because of their broad tissue tropisms and the relative ease with which they can be genetically altered, adenoviruses have been a vector of choice for gene therapy protocols, representing almost one-fourth of all vectors used in current gene therapy clinical trials (http://www.abedia.com/wiley/vectors.php). Recently, due to their low seroprevalence, HAdV-D vectors are being tested for use in gene therapy (HAdVD19, D26, D28, D46, D48, D49) (Abbink et al., 2007; Kahl et al., 2010; Lemckert et al., 2006; Reddy et al., 2006; Ruzsics et al., 2006; Thirion et al., 2006). It is critically important to understand recombination mechanisms in HAdV-Ds if gene vectors based on HAdV-Ds are to be used in human patients who might become coincidently infected with a wild type virus. The complete genome sequences of most prototype HAdV genomes are currently deposited in GenBank. The remaining $20 \mathrm{HAdV}-\mathrm{D}$ whole genome sequences are currently being finished, and once complete, will allow an in-depth analysis of adenovirus recombination not previously possible.

In part because of the recently reduced cost and ease of whole genome sequencing, and with improvement in bioinformatics methods, recombination between adenoviruses has become an area of intense interest. Using bootscan analysis, recombination has been described in many fully sequenced HAdV genomes (Lukashev et al., 2008; Robinson et al., 2009a; Robinson et al., 2011; Walsh et al., 2009; Walsh et al., 2010). This has led to the recognition of recombination hot spots (Fig. 5). The areas of the genome commonly associated with 
homologous recombination - and incidentally among the most variable - include the penton base, hexon and fiber coding regions. Interestingly, protein products of these regions of the genome mediate interaction between the virus and the target cell during initial infection, and are crucially important to host immune system recognition of the virus. In HAdV-D22, recombination takes place in the penton base gene centered around the hypervariable and the RGD loops, both of which are exposed on the outside face of the viral capsid. HAdV-D37 shares a large portion of its genome with clinical isolates of HAdV-D19 from patients with epidemic keratoconjunctivitis. For HAdV-D53, recombination was identified in penton, hexon and fiber between HAdV-D22, D37, and D8, respectively. HAdV-D56 was identified as a recombinant between HAdV-D9 and D15, D26, and/or D29. The mechanism(s) for homologous recombination within HAdVs remains unidentified, but once understood, may endow us with the capacity to predict potential emerging HAdV types.

\section{References}

Gene Therapy Clinical Trials Worldwide. [January 27, 2011] J Gene Med. 2010. http://www.abedia.com/wiley/vectors.php

Abbink P, Lemckert AA, Ewald BA, Lynch DM, Denholtz M, Smits S, Holterman L, Damen I, Vogels R, Thorner AR, O'Brien KL, Carville A, Mansfield KG, Goudsmit J, Havenga MJ, Barouch DH. Comparative seroprevalence and immunogenicity of six rare serotype recombinant adenovirus vaccine vectors from subgroups B and D. J Virol. 2007; 81:4654-4663. [PubMed: 17329340]

Adrian T, Bastian B, Benoist W, Hierholzer JC, Wigand R. Characterization of adenovirus 15/H9 intermediate strains. Intervirology. 1985; 23:15-22. [PubMed: 2982756]

Adrian T, Wigand R. Adenovirus 3-7, an intermediate strain of subgenus B. Intervirology. 1986; 26:202-206. [PubMed: 3038773]

Adrian T, Wigand R, Wadell G. Serological and biochemical characteristics of intermediate adenovirus strains of subgenus D. Arch Virol. 1987; 97:347-357. [PubMed: 2827612]

Aoki K, Ishiko H, Konno T, Shimada Y, Hayashi A, Kaneko H, Ohguchi T, Tagawa Y, Ohno S, Yamazaki S. Epidemic keratoconjunctivitis due to the novel hexon-chimeric-intermediate 22,37/H8 human adenovirus. J Clin Microbiol. 2008; 46:3259-3269. [PubMed: 18701656]

Arnberg N, Edlund K, Kidd AH, Wadell G. Adenovirus type 37 uses sialic acid as a cellular receptor. J Virol. 2000; 74:42-48. [PubMed: 10590089]

Arnberg N, Pring-Akerblom P, Wadell G. Adenovirus type 37 uses sialic acid as a cellular receptor on Chang C cells. J Virol. 2002; 76:8834-8841. [PubMed: 12163603]

Arnold J, Janoska M, Kajon AE, Metzgar D, Hudson NR, Torres S, Harrach B, Seto D, Chodosh J, Jones MS. Genomic characterization of human adenovirus 36, a putative obesity agent. Virus Res. 2010; 149:152-161. [PubMed: 20109503]

Atkinson RL, Dhurandhar NV, Allison DB, Bowen RL, Israel BA, Albu JB, Augustus AS. Human adenovirus-36 is associated with increased body weight and paradoxical reduction of serum lipids. Int J Obes (Lond). 2005; 29:281-286. [PubMed: 15611785]

Bell SD Jr. Mc CD, Murray ES, Chang RS, Snyder JC. Adenoviruses isolated from Saudi Arabia. I. Epidemiologic features. Am J Trop Med Hyg. 1959; 8:492-500. [PubMed: 13670377]

Benedict CA, Norris PS, Prigozy TI, Bodmer JL, Mahr JA, Garnett CT, Martinon F, Tschopp J, Gooding LR, Ware CF. Three adenovirus E3 proteins cooperate to evade apoptosis by tumor necrosis factor-related apoptosis-inducing ligand receptor-1 and -2. J Biol Chem. 2001; 276:32703278. [PubMed: 11050095]

Bergelson JM, Cunningham JA, Droguett G, Kurt-Jones EA, Krithivas A, Hong JS, Horwitz MS, Crowell RL, Finberg RW. Isolation of a common receptor for Coxsackie B viruses and adenoviruses 2 and 5. Science. 1997; 275:1320-1323. [PubMed: 9036860]

Berget SM, Moore C, Sharp PA. Spliced segments at the 5' terminus of adenovirus 2 late mRNA. Proc Natl Acad Sci U S A. 1977; 74:3171-3175. [PubMed: 269380]

Bhat BM, Wold WS. Genetic analysis of mRNA synthesis in adenovirus region E3 at different stages of productive infection by RNA-processing mutants. J Virol. 1986; 60:54-63. [PubMed: 3747028] 
Boulay JL, Perruchoud AP, Reuter J, Bolliger C, Herrmann R, Rochlitz C. P21 gene expression as an indicator for the activity of adenovirus-p53 gene therapy in non-small cell lung cancer patients. Cancer Gene Ther. 2000; 7:1215-1219. [PubMed: 11023193]

Boursnell ME, Mautner V. Recombination in adenovirus: crossover sites in intertypic recombinants are located in regions of homology. Virology. 1981; 112:198-209. [PubMed: 6264680]

Burgert HG, Blusch JH. Immunomodulatory functions encoded by the E3 transcription unit of adenoviruses. Virus Genes. 2000; 21:13-25. [PubMed: 11022786]

Burgert HG, Maryanski JL, Kvist S. "E3/19K" protein of adenovirus type 2 inhibits lysis of cytolytic T lymphocytes by blocking cell-surface expression of histocompatibility class I antigens. Proc Natl Acad Sci U S A. 1987; 84:1356-1360. [PubMed: 2950523]

Chiu CY, Wu E, Brown SL, Von Seggern DJ, Nemerow GR, Stewart PL. Structural analysis of a fiber-pseudotyped adenovirus with ocular tropism suggests differential modes of cell receptor interactions. J Virol. 2001; 75:5375-5380. [PubMed: 11333920]

Chow LT, Broker TR. The spliced structures of adenovirus 2 fiber message and the other late mRNAs. Cell. 1978; 15:497-510. [PubMed: 719751]

Chow LT, Broker TR, Lewis JB. Complex splicing patterns of RNAs from the early regions of adenovirus-2. J Mol Biol. 1979; 134:265-303. [PubMed: 537065]

Chow LT, Gelinas RE, Broker TR, Roberts RJ. An amazing sequence arrangement at the 5' ends of adenovirus 2 messenger RNA. Cell. 1977a; 12:1-8. [PubMed: 902310]

Chow LT, Lewis JB, Broker TR. RNA transcription and splicing at early and intermediate times after adenovirus-2 infection. Cold Spring Harb Symp Quant Biol. 1980; 44(Pt 1):401-414. [PubMed: 6933037]

Chow LT, Roberts JM, Lewis JB, Broker TR. A map of cytoplasmic RNA transcripts from lytic adenovirus type 2, determined by electron microscopy of RNA:DNA hybrids. Cell. 1977b; 11:819-836. [PubMed: 890740]

Chroboczek J, Ruigrok RW, Cusack S. Adenovirus fiber. Curr Top Microbiol Immunol. 1995; 199(Pt 1):163-200. [PubMed: 7555054]

Chu W, Pavan-Langston D. Ocular surface manifestations of the major viruses. Int Ophthalmol Clin. 1979; 19:135-167. [PubMed: 222704]

Crawford-Miksza L, Schnurr DP. Analysis of 15 adenovirus hexon proteins reveals the location and structure of seven hypervariable regions containing serotype-specific residues. J Virol. 1996; 70:1836-1844. [PubMed: 8627708]

Crawford-Miksza LK, Nang RN, Schnurr DP. Strain variation in adenovirus serotypes 4 and 7a causing acute respiratory disease. J Clin Microbiol. 1999; 37:1107-1112. [PubMed: 10074533]

Crystal RG, McElvaney NG, Rosenfeld MA, Chu CS, Mastrangeli A, Hay JG, Brody SL, Jaffe HA, Eissa NT, Danel C. Administration of an adenovirus containing the human CFTR cDNA to the respiratory tract of individuals with cystic fibrosis. Nat Genet. 1994; 8:42-51. [PubMed: 7527271]

Curlin ME, Huang ML, Lu X, Celum CL, Sanchez J, Selke S, Baeten JM, Zuckerman RA, Erdman $\mathrm{DD}$, Corey L. Frequent detection of human adenovirus from the lower gastrointestinal tract in men who have sex with men. PLoS ONE. 2010; 5:e11321. [PubMed: 20593015]

Cypel M, Liu M, Rubacha M, Yeung JC, Hirayama S, Anraku M, Sato M, Medin J, Davidson BL, de Perrot M, Waddell TK, Slutsky AS, Keshavjee S. Functional repair of human donor lungs by IL-10 gene therapy. Sci Transl Med. 2009; 1:4ra9.

Darr S, Madisch I, Hofmayer S, Rehren F, Heim A. Phylogeny and primary structure analysis of fiber shafts of all human adenovirus types for rational design of adenoviral gene-therapy vectors. J Gen Virol. 2009; 90:2849-2854. [PubMed: 19656960]

Davison AJ, Benko M, Harrach B. Genetic content and evolution of adenoviruses. J Gen Virol. 2003; 84:2895-2908. [PubMed: 14573794]

De Jong JC, Wermenbol AG, Verweij-Uijterwaal MW, Slaterus KW, Wertheim-Van Dillen P, Van Doornum GJ, Khoo SH, Hierholzer JC. Adenoviruses from human immunodeficiency virusinfected individuals, including two strains that represent new candidate serotypes Ad50 and Ad51 of species B1 and D, respectively. J Clin Microbiol. 1999; 37:3940-3945. [PubMed: 10565911] 
de Jong JC, Wigand R, Wadell G, Keller D, Muzerie CJ, Wermenbol AG, Schaap GJ. Adenovirus 37: identification and characterization of a medically important new adenovirus type of subgroup D. J Med Virol. 1981; 7:105-118. [PubMed: 7264611]

Deryckere F, Burgert HG. Early region 3 of adenovirus type 19 (subgroup D) encodes an HLAbinding protein distinct from that of subgroups B and C. J Virol. 1996; 70:2832-2841. [PubMed: 8627757]

Dhurandhar NV, Israel BA, Kolesar JM, Mayhew GF, Cook ME, Atkinson RL. Increased adiposity in animals due to a human virus. Int J Obes Relat Metab Disord. 2000; 24:989-996. [PubMed: 10951537]

Dingle JH, Langmuir AD. Epidemiology of acute, respiratory disease in military recruits. Am Rev Respir Dis. 1968; 97(Suppl):1-65. [PubMed: 4869845]

Engelmann I, Madisch I, Pommer H, Heim A. An outbreak of epidemic keratoconjunctivitis caused by a new intermediate adenovirus 22/H8 identified by molecular typing. Clin Infect Dis. 2006; 43:e64-66. [PubMed: 16941356]

Feuerbach D, Etteldorf S, Ebenau-Jehle C, Abastado JP, Madden D, Burgert HG. Identification of amino acids within the MHC molecule important for the interaction with the adenovirus protein E3/19K. J Immunol. 1994; 153:1626-1636. [PubMed: 8046235]

Fox JP, Hall CE, Cooney MK. The Seattle Virus Watch. VII. Observations of adenovirus infections. Am J Epidemiol. 1977; 105:362-386. [PubMed: 192073]

Garnett CT, Erdman D, Xu W, Gooding LR. Prevalence and quantitation of species C adenovirus DNA in human mucosal lymphocytes. J Virol. 2002; 76:10608-10616. [PubMed: 12368303]

Grodzicker T, Williams J, Sharp P, Sambrook J. Physical mapping of temperature-sensitive mutations of adenoviruses. Cold Spring Harb Symp Quant Biol. 1975; 39(Pt 1):439-446. [PubMed: 169087]

Hawkins LK, Wold WS. A 12,500 MW protein is coded by region E3 of adenovirus. Virology. 1992; 188:486-494. [PubMed: 1585632]

Hedman M, Hartikainen J, Syvanne M, Stjernvall J, Hedman A, Kivela A, Vanninen E, Mussalo H, Kauppila E, Simula S, Narvanen O, Rantala A, Peuhkurinen K, Nieminen MS, Laakso M, YlaHerttuala S. Safety and feasibility of catheter-based local intracoronary vascular endothelial growth factor gene transfer in the prevention of postangioplasty and in-stent restenosis and in the treatment of chronic myocardial ischemia: phase II results of the Kuopio Angiogenesis Trial (KAT). Circulation. 2003; 107:2677-2683. [PubMed: 12742981]

Henquell C, Boeuf B, Mirand A, Bacher C, Traore O, Dechelotte P, Labbe A, Bailly JL, PeigueLafeuille H. Fatal adenovirus infection in a neonate and transmission to health-care workers. J Clin Virol. 2009; 45:345-348. [PubMed: 19477681]

Hierholzer JC, Adrian T, Anderson LJ, Wigand R, Gold JW. Analysis of antigenically intermediate strains of subgenus B and D adenoviruses from AIDS patients. Arch Virol. 1988a; 103:99-115. [PubMed: 2850781]

Hierholzer JC, Kemp MC, Gary GW Jr. Spencer HC. New human adenovirus associated with respiratory illness: candidate adenovirus type 39. J Clin Microbiol. 1982; 16:15-21. [PubMed: 6179962]

Hierholzer JC, Stone YO, Broderson JR. Antigenic relationships among the 47 human adenoviruses determined in reference horse antisera. Arch Virol. 1991; 121:179-197. [PubMed: 1759904]

Hierholzer JC, Torrence AE, Wright PF. Generalized viral illness caused by an intermediate strain of adenovirus (21/H21 + 35). J Infect Dis. 1980; 141:281-288. [PubMed: 6245153]

Hierholzer JC, Wigand R, Anderson LJ, Adrian T, Gold JW. Adenoviruses from patients with AIDS: a plethora of serotypes and a description of five new serotypes of subgenus D (types 43-47). J Infect Dis. 1988b; 158:804-813. [PubMed: 2844918]

Hilgendorf A, Lindberg J, Ruzsics Z, Honing S, Elsing A, Lofqvist M, Engelmann H, Burgert HG. Two distinct transport motifs in the adenovirus E3/10.4-14.5 proteins act in concert to downmodulate apoptosis receptors and the epidermal growth factor receptor. J Biol Chem. 2003; 278:51872-51884. [PubMed: 14506242]

Hilleman MR, Werner JH. Recovery of new agent from patients with acute respiratory illness. Proc Soc Exp Biol Med. 1954; 85:183-188. [PubMed: 13134329] 
Horvath J, Palkonyay L, Weber J. Group C adenovirus DNA sequences in human lymphoid cells. J Virol. 1986; 59:189-192. [PubMed: 3486983]

Horwitz MS, Valderrama G, Hatcher V, Korn R, deJong P, Spigland I. Characterization of adenovirus isolates from AIDS patients. Ann N Y Acad Sci. 1984; 437:161-174. [PubMed: 6099998]

Ishiko H, Shimada Y, Konno T, Hayashi A, Ohguchi T, Tagawa Y, Aoki K, Ohno S, Yamazaki S. Novel human adenovirus causing nosocomial epidemic keratoconjunctivitis. J Clin Microbiol. 2008; 46:2002-2008. [PubMed: 18385435]

Jager L, Ehrhardt A. Emerging adenoviral vectors for stable correction of genetic disorders. Curr Gene Ther. 2007; 7:272-283. [PubMed: 17969560]

Jawetz E, Kimura S, Nicholas AN, Thygeson P, Hanna L. new type of APC virus from epidemic keratoconjunctivitis. Science. 1955; 122:1190-1191. [PubMed: 13274081]

Jones MS 2nd, Harrach B, Ganac RD, Gozum MM, Dela Cruz WP, Riedel B, Pan C, Delwart EL, Schnurr DP. New adenovirus species found in a patient presenting with gastroenteritis. J Virol. 2007; 81:5978-5984. [PubMed: 17360747]

Kahl CA, Bonnell J, Hiriyanna S, Fultz M, Nyberg-Hoffman C, Chen P, King CR, Gall JG. Potent immune responses and in vitro pro-inflammatory cytokine suppression by a novel adenovirus vaccine vector based on rare human serotype 28. Vaccine. 2010; 28:5691-5702. [PubMed: 20600496]

Kajon AE, Dickson LM, Murtagh P, Viale D, Carballal G, Echavarria M. Molecular characterization of an adenovirus 3-16 intertypic recombinant isolated in Argentina from an infant hospitalized with acute respiratory infection. J Clin Microbiol. 2010; 48:1494-1496. [PubMed: 20129962]

Kaneko H, Aoki K, Ohno S, Ishiko H, Fujimoto T, Kikuchi M, Harada S, Gonzalez G, Koyanagi KO, Watanabe H, Suzutani T. Complete genome analysis of a novel intertypic recombinant human adenovirus causing epidemic keratoconjunctivitis in Japan. J Clin Microbiol. 2010

Kaneko H, Iida T, Ishiko H, Ohguchi T, Ariga T, Tagawa Y, Aoki K, Ohno S, Suzutani T. Analysis of the complete genome sequence of epidemic keratoconjunctivitis-related human adenovirus type 8 , 19, 37 and a novel serotype. J Gen Virol. 2009; 90:1471-1476. [PubMed: 19264666]

Kaneko H, Suzutani T, Aoki K, Kitaichi N, Ishida S, Ishiko H, Ohashi T, Okamoto S, Nakagawa H, Hinokuma R, Asato Y, Oniki S, Hashimoto T, Iida T, Ohno S. Epidemiological and virological features of epidemic keratoconjunctivitis due to new human adenovirus type 54 in Japan. $\mathrm{Br} \mathrm{J}$ Ophthalmol. 2011; 95:32-36. [PubMed: 20530657]

Kim YJ, Schmidt NJ, Mirkovic RR. Isolation of an intermediate type of adenovirus from a child with fulminant hepatitis. J Infect Dis. 1985; 152:844. [PubMed: 4045236]

Kojaoghlanian T, Flomenberg P, Horwitz MS. The impact of adenovirus infection on the immunocompromised host. Rev Med Virol. 2003; 13:155-171. [PubMed: 12740831]

Lasaro MO, Ertl HC. New insights on adenovirus as vaccine vectors. Mol Ther. 2009; 17:1333-1339. [PubMed: 19513019]

Lemckert AA, Grimbergen J, Smits S, Hartkoorn E, Holterman L, Berkhout B, Barouch DH, Vogels R, Quax P, Goudsmit J, Havenga MJ. Generation of a novel replication-incompetent adenoviral vector derived from human adenovirus type 49: manufacture on PER.C6 cells, tropism and immunogenicity. J Gen Virol. 2006; 87:2891-2899. [PubMed: 16963747]

Li E, Brown SL, Stupack DG, Puente XS, Cheresh DA, Nemerow GR. Integrin alpha(v)beta1 is an adenovirus coreceptor. J Virol. 2001; 75:5405-5409. [PubMed: 11333925]

Li Y, Wold WS. Identification and characterization of a 30K protein (Ad4E3-30K) encoded by the E3 region of human adenovirus type 4. Virology. 2000; 273:127-138. [PubMed: 10891415]

Lippin Y, Dranitzki-Elhalel M, Brill-Almon E, Mei-Zahav C, Mizrachi S, Liberman Y, Iaina A, Kaplan E, Podjarny E, Zeira E, Harati M, Casadevall N, Shani N, Galun E. Human erythropoietin gene therapy for patients with chronic renal failure. Blood. 2005; 106:2280-2286. [PubMed: 15798000]

Lu X, Erdman DD. Molecular typing of human adenoviruses by PCR and sequencing of a partial region of the hexon gene. Arch Virol. 2006; 151:1587-1602. [PubMed: 16502282]

Lukashev AN, Ivanova OE, Eremeeva TP, Iggo RD. Evidence of frequent recombination among human adenoviruses. J Gen Virol. 2008; 89:380-388. [PubMed: 18198368] 
Macek V, Sorli J, Kopriva S, Marin J. Persistent adenoviral infection and chronic airway obstruction in children. Am J Respir Crit Care Med. 1994; 150:7-10. [PubMed: 8025775]

Madisch I, Hofmayer S, Moritz C, Grintzalis A, Hainmueller J, Pring-Akerblom P, Heim A. Phylogenetic analysis and structural predictions of human adenovirus penton proteins as a basis for tissue-specific adenovirus vector design. J Virol. 2007; 81:8270-8281. [PubMed: 17522221]

Marin J, Jeler-Kacar D, Levstek V, Macek V. Persistence of viruses in upper respiratory tract of children with asthma. J Infect. 2000; 41:69-72. [PubMed: 10942643]

Matumoto M, Uchida S, Hoshika T. Isolation of an intermediate type of adenovirus from a fatal case of infantile pneumonia. Jpn J Exp Med. 1958; 28:305-315. [PubMed: 13587045]

Mautner V, Williams J, Sambrook J, Sharp PA, Grodzicker T. The location of the genes coding for hexon and fiber proteins in adenovirus DNA. Cell. 1975; 5:93-99. [PubMed: 48427]

Meinschad C, Winnacker EL. Recombination in adenovirus. I. Analysis of recombinant viruses under non-selective conditions. J Gen Virol. 1980; 48:219-224. [PubMed: 6247436]

Nilsson EC, Storm RJ, Bauer J, Johansson SM, Lookene A, Angstrom J, Hedenstrom M, Eriksson TL, Frangsmyr L, Rinaldi S, Willison HJ, Domellof FP, Stehle T, Arnberg N. The GD1a glycan is a cellular receptor for adenoviruses causing epidemic keratoconjunctivitis. Nat Med. 2011; 17:105109. [PubMed: 21151139]

Norby E. Comparative studies on the soluble components of adenovirus types 9 and 15 and the intermediate strain 9-15. J Virol. 1968; 2:1200-1210. [PubMed: 5723744]

Parks WP, Queiroga LM, Melnick JL, Pereira HG. Recent adenovirus isolates exhibiting broad intratypic and intertypic antigenicity. Proc Soc Exp Biol Med. 1967; 125:498-503. [PubMed: 6028572]

Phillips PA, Harnett GB, Gollow MM. Adenovirus type 19 and a closely related new serotype in genital infection. Br J Vener Dis. 1982; 58:131-132. [PubMed: 7066666]

Pichla-Gollon SL, Lin SW, Hensley SE, Lasaro MO, Herkenhoff-Haut L, Drinker M, Tatsis N, Gao GP, Wilson JM, Ertl HC, Bergelson JM. Effect of preexisting immunity on an adenovirus vaccine vector: in vitro neutralization assays fail to predict inhibition by antiviral antibody in vivo. J Virol. 2009; 83:5567-5573. [PubMed: 19279092]

Reddy PS, Ganesh S, Knowles NJ, Kaleko M, Connelly S, Bristol A. Complete sequence and organization of the human adenovirus serotype 46 genome. Virus Res. 2006; 116:119-128. [PubMed: 16242804]

Robinson CM, Rajaiya J, Walsh MP, Seto D, Dyer DW, Jones MS, Chodosh J. Computational analysis of human adenovirus type 22 provides evidence for recombination among species D human adenoviruses in the penton base gene. J Virol. 2009a; 83:8980-8985. [PubMed: 19553309]

Robinson CM, Shariati F, Gillaspy AF, Dyer DW, Chodosh J. Genomic and bioinformatics analysis of human adenovirus type 37: new insights into corneal tropism. BMC Genomics. 2008; 9:213. [PubMed: 18471294]

Robinson CM, Shariati F, Zaitshik J, Gillaspy AF, Dyer DW, Chodosh J. Human adenovirus type 19: Genomic and bioinformatics analysis of a keratoconjunctivitis isolate. Virus Res. 2009b; 139:122126. [PubMed: 19000724]

Robinson CM, Singh G, Henquell C, Walsh MP, Peigue-Lafeuille H, Seto D, Jones MS, Dyer DW, Chodosh J. Computational analysis and identification of an emergent human adenovirus pathogen implicated in a respiratory fatality. Virology. 2011; 409:141-147. [PubMed: 21056888]

Rosen L, Baron S, Bell JA. Four newly recognized adenoviruses. Proc Soc Exp Biol Med. 1961; 107:434-437. [PubMed: 13743340]

Rosen L, Hovis JF, Bell JA. Further observation on typing adenoviruses and a description of two possible additional serotypes. Proc Soc Exp Biol Med. 1962; 110:710-713. [PubMed: 14493907]

Rowe WP, Huebner RJ, Gilmore LK, Parrott RH, Ward TG. Isolation of a cytopathogenic agent from human adenoids undergoing spontaneous degeneration in tissue culture. Proc Soc Exp Biol Med. 1953; 84:570-573. [PubMed: 13134217]

Ruzsics Z, Wagner M, Osterlehner A, Cook J, Koszinowski U, Burgert HG. Transposon-assisted cloning and traceless mutagenesis of adenoviruses: Development of a novel vector based on species D. J Virol. 2006; 80:8100-8113. [PubMed: 16873266] 
Sambrook J, Williams J, Sharp PA, Grodzicker T. Physical mapping of temperature-sensitive mutations of adenoviruses. J Mol Biol. 1975; 97:369-390. [PubMed: 171416]

Schnurr D, Dondero ME. Two new candidate adenovirus serotypes. Intervirology. 1993; 36:79-83. [PubMed: 8294185]

Seto D, Chodosh J, Brister JR, Jones MS. Using the whole genome sequence to characterize and name human adenoviruses. J Virol. 2011

Smith JG, Wiethoff CM, Stewart PL, Nemerow GR. Adenovirus. Curr Top Microbiol Immunol. 2010; 343:195-224. [PubMed: 20376613]

Stevens DA, Schaeffer M, Fox JP, Brandt CD, Romano M. Standardization and certification of reference antigens and antisera for 30 human adenovirus serotypes. Am J Epidemiol. 1967; 86:617-633. [PubMed: 6081385]

Stewart AK, Lassam NJ, Quirt IC, Bailey DJ, Rotstein LE, Krajden M, Dessureault S, Gallinger S, Cappe D, Wan Y, Addison CL, Moen RC, Gauldie J, Graham FL. Adenovector-mediated gene delivery of interleukin-2 in metastatic breast cancer and melanoma: results of a phase 1 clinical trial. Gene Ther. 1999; 6:350-363. [PubMed: 10435085]

Stewart PL, Chiu CY, Huang S, Muir T, Zhao Y, Chait B, Mathias P, Nemerow GR. Cryo-EM visualization of an exposed RGD epitope on adenovirus that escapes antibody neutralization. EMBO J. 1997; 16:1189-1198. [PubMed: 9135136]

Swenson PD, Lowens MS, Celum CL, Hierholzer JC. Adenovirus types 2, 8, and 37 associated with genital infections in patients attending a sexually transmitted disease clinic. J Clin Microbiol. 1995; 33:2728-2731. [PubMed: 8567914]

Takemori N. Genetic studies with tumorigenic adenoviruses. 3. Recombination in adenovirus type 12. Virology. 1972; 47:157-167. [PubMed: 5058331]

Thirion C, Lochmuller H, Ruzsics Z, Boelhauve M, Konig C, Thedieck C, Kutik S, Geiger C, Kochanek S, Volpers C, Burgert HG. Adenovirus vectors based on human adenovirus type 19a have high potential for human muscle-directed gene therapy. Hum Gene Ther. 2006; 17:193205. [PubMed: 16454653]

Toogood CI, Crompton J, Hay RT. Antipeptide antisera define neutralizing epitopes on the adenovirus hexon. J Gen Virol. 1992; 73(Pt 6):1429-1435. [PubMed: 1376769]

Top FH Jr. Buescher EL, Bancroft WH, Russell PK. Immunization with live types 7 and 4 adenovirus vaccines. II. Antibody response and protective effect against acute respiratory disease due to adenovirus type 7. J Infect Dis. 1971a; 124:155-160. [PubMed: 4330998]

Top FH Jr. Grossman RA, Bartelloni PJ, Segal HE, Dudding BA, Russell PK, Buescher EL. Immunization with live types 7 and 4 adenovirus vaccines. I. Safety, infectivity, antigenicity, and potency of adenovirus type 7 vaccine in humans. J Infect Dis. 1971b; 124:148-154. [PubMed: 4330997]

van der Linden RR, Haagmans BL, Mongiat-Artus P, van Doornum GJ, Kraaij R, Kadmon D, AguilarCordova E, Osterhaus AD, van der Kwast TH, Bangma CH. Virus specific immune responses after human neoadjuvant adenovirus-mediated suicide gene therapy for prostate cancer. Eur Urol. 2005; 48:153-161. [PubMed: 15967266]

Vora GJ, Lin B, Gratwick K, Meador C, Hansen C, Tibbetts C, Stenger DA, Irvine M, Seto D, Purkayastha A, Freed NE, Gibson MG, Russell K, Metzgar D. Co-infections of adenovirus species in previously vaccinated patients. Emerg Infect Dis. 2006; 12:921-930. [PubMed: 16707047]

Walsh MP, Chintakuntlawar A, Robinson CM, Madisch I, Harrach B, Hudson NR, Schnurr D, Heim A, Chodosh J, Seto D, Jones MS. Evidence of molecular evolution driven by recombination events influencing tropism in a novel human adenovirus that causes epidemic keratoconjunctivitis. PLoS ONE. 2009; 4:e5635. [PubMed: 19492050]

Walsh MP, Seto J, Jones MS, Chodosh J, Xu W, Seto D. Computational analysis identifies human adenovirus type 55 as a re-emergent acute respiratory disease pathogen. J Clin Microbiol. 2010; 48:991-993. [PubMed: 20042633]

Whyte P, Buchkovich KJ, Horowitz JM, Friend SH, Raybuck M, Weinberg RA, Harlow E. Association between an oncogene and an anti-oncogene: the adenovirus E1A proteins bind to the retinoblastoma gene product. Nature. 1988; 334:124-129. [PubMed: 2968522] 
Wickham TJ, Mathias P, Cheresh DA, Nemerow GR. Integrins alpha v beta 3 and alpha v beta 5 promote adenovirus internalization but not virus attachment. Cell. 1993; 73:309-319. [PubMed: 8477447]

Wiethoff CM, Wodrich H, Gerace L, Nemerow GR. Adenovirus protein VI mediates membrane disruption following capsid disassembly. J Virol. 2005; 79:1992-2000. [PubMed: 15681401]

Wigand R. Pitfalls in the identification of adenoviruses. J Virol Methods. 1987; 16:161-169. [PubMed: 2821047]

Wigand R, Fliedner D. Serologically intermediate adenovirus strains: a regular feature of group II adenoviruses. Arch Gesamte Virusforsch. 1968; 24:245-256. [PubMed: 5698889]

Wigand R, Keller D, Werling I. Immunological relationship among human adenoviruses of subgenus D. Arch Virol. 1982; 72:199-209. [PubMed: 6180704]

Williams J, Grodzicker T, Sharp P, Sambrook J. Adenovirus recombination: physical mapping of crossover events. Cell. 1975a; 4:113-119. [PubMed: 804996]

Williams J, Young H, Austin P. Complementation of human adenovirus type 5 ts mutants by human adenovirus type 12. J Virol. 1975b; 15:675-678. [PubMed: 1113379]

Williams JF, Gharpure M, Ustacelebi S, McDonald S. Isolation of temperature-sensitive mutants of adenovirus type 5. J Gen Virol. 1971; 11:95-101. [PubMed: 5564419]

Williams JF, Ustacelebi S. Complementation and recombination with temperature-sensitive mutants of adenovirus type 5. J Gen Virol. 1971; 13:345-348. [PubMed: 5157831]

Wood DJ. Adenovirus gastroenteritis. Br Med J (Clin Res Ed). 1988; 296:229-230.

Wu E, Pache L, Von Seggern DJ, Mullen TM, Mikyas Y, Stewart PL, Nemerow GR. Flexibility of the adenovirus fiber is required for efficient receptor interaction. J Virol. 2003; 77:7225-7235. [PubMed: 12805421]

Wu E, Trauger SA, Pache L, Mullen TM, von Seggern DJ, Siuzdak G, Nemerow GR. Membrane cofactor protein is a receptor for adenoviruses associated with epidemic keratoconjunctivitis. $\mathbf{J}$ Virol. 2004; 78:3897-3905. [PubMed: 15047806]

Young CS, Cachianes G, Munz P, Silverstein S. Replication and recombination in adenovirus-infected cells are temporally and functionally related. J Virol. 1984; 51:571-577. [PubMed: 6471165]

Young CS, Silverstein SJ. The kinetics of adenovirus recombination in homotypic and heterotypic genetic crosses. Virology. 1980; 101:503-515. [PubMed: 7361457]

Zubieta C, Schoehn G, Chroboczek J, Cusack S. The structure of the human adenovirus 2 penton. Mol Cell. 2005; 17:121-135. [PubMed: 15629723] 


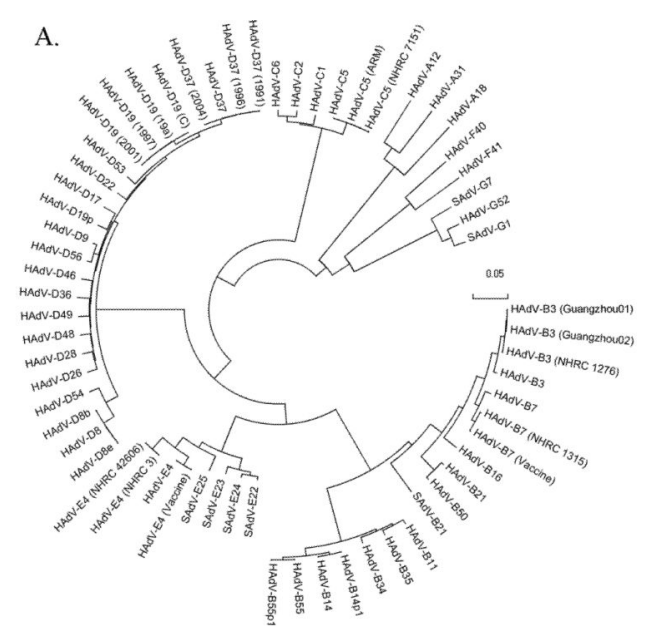

B.

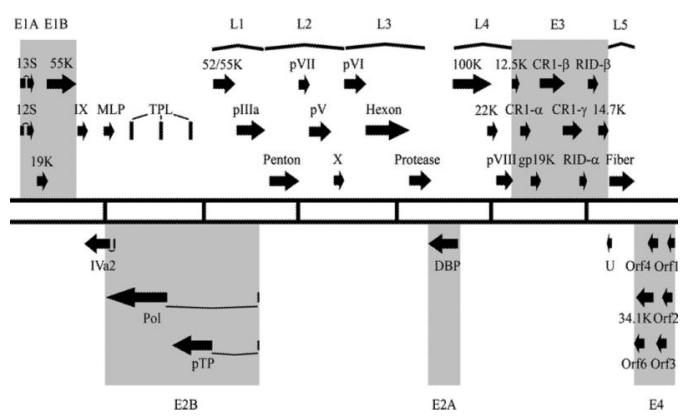

Figure 1.

Genomic analysis of human adenoviruses. (A) Whole genome bootstrap neighbor joining phylogenetic tree designed with MEGA 4.0. Species of adenoviruses are denoted. Adapted from (Robinson et al., 2011). (B) Transcriptional map of human adenovirus species D. The two central lines define the length of the HAdV-D genome with every vertical line representing 5000 bps. Black Arrows represent predicted protein coding regions. Early transcription units (E) are highlighted. Late transcription units (L) are shown by parentheses. 


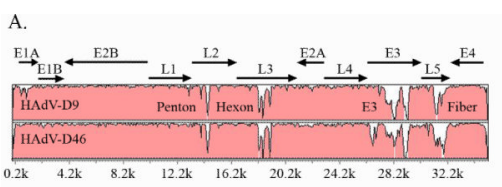

B.

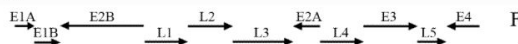

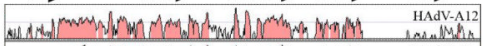

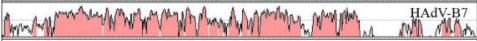

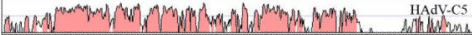

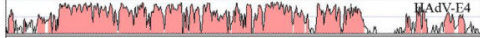

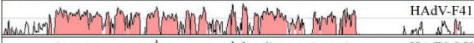

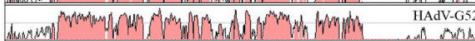
$\begin{array}{llllllllll}0.2 \mathrm{k} & 4.2 \mathrm{k} & 8.2 \mathrm{k} & 12.2 \mathrm{k} & 16.2 \mathrm{k} & 20.2 \mathrm{k} & 24.2 \mathrm{k} & 28.2 \mathrm{k} & 32.2 \mathrm{k}\end{array}$

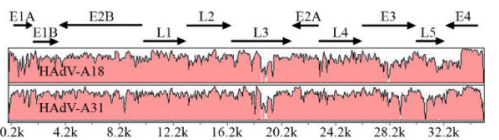
D.

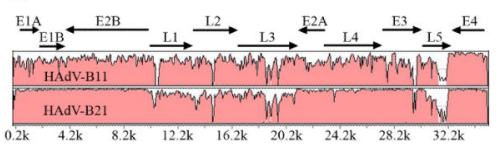

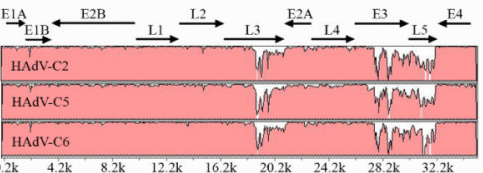
F.

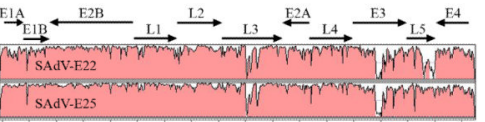

$\begin{array}{llllllllllll}0.2 \mathrm{k} & 4.2 \mathrm{k} & 8.2 \mathrm{k} & 12.2 \mathrm{k} & 16.2 \mathrm{k} & 20.2 \mathrm{k} & 24.2 \mathrm{k} & 28.2 \mathrm{k} & 32.2 \mathrm{k}\end{array}$ G.

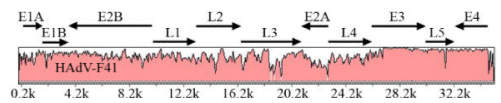

$\mathrm{H}$.

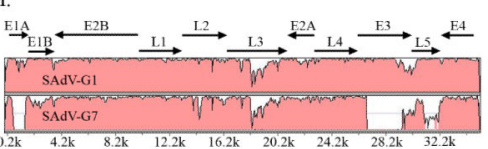

Figure 2.

mVISTA global pairwise sequence alignment analysis of human adenoviruses. (A) HAdVD37 compared to representative members of HAdV species D (B) HAdV-D37 compared to a representative type from each of the 6 other HAdV species. Adapted from (Robinson et al., 2008). (C) HAdV-A12 compared to other members of HAdV species A. (D) HAdV-B3 compared to representative members of HAdV species B (E) HAdV-C1 compared to members of HAdV-C. (F) HAdV-E4 compared to two SAdV types classified in HAdV-E. (G) HAdV-F40 compared to HAdV-F41. (H) HAdV-G52 compared to members of SAdV classified in HAdV-G. 

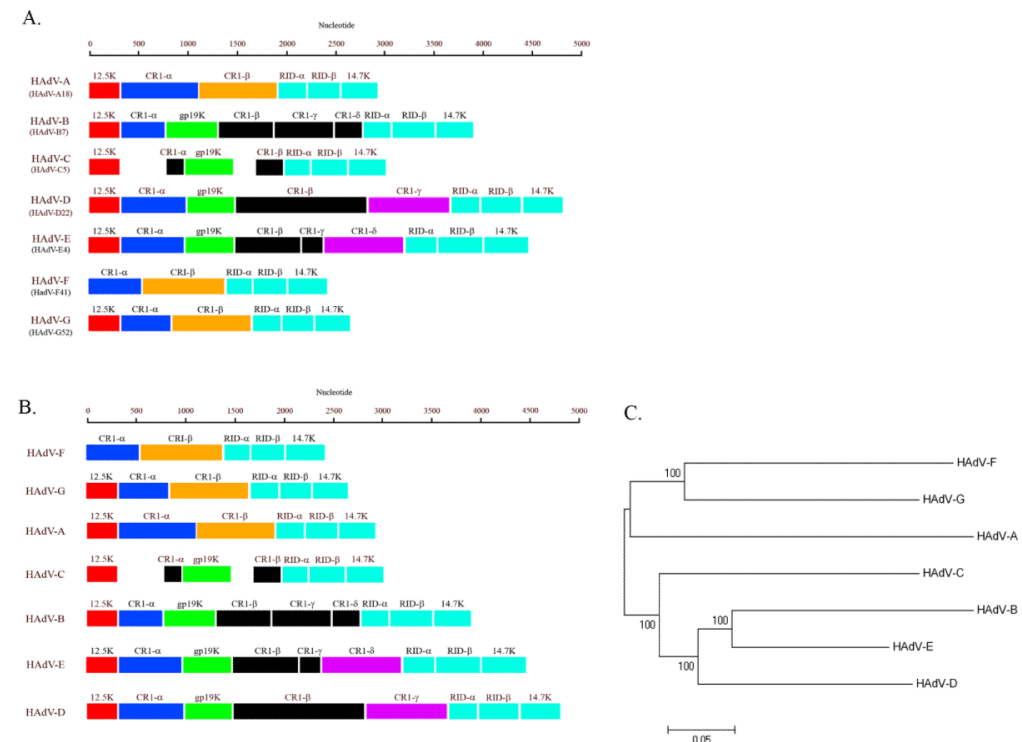

Figure 3.

HAdV E3 genomic analysis. (A) Annotation of E3 transcription units from a representative HAdV type for each of the seven species. (B) Annotation of the E3 transcription units from each species, arranged by length of the coding sequence. (C) Phylogenetic analysis of whole genome sequence from a representative HAdV type representing each of the seven species. Red, Blue, Orange, Green, Purple, and Teal represent conserved annotated genes in multiple $\mathrm{HAdV}$ species. Black represents species-specific annotated genes. 
A.
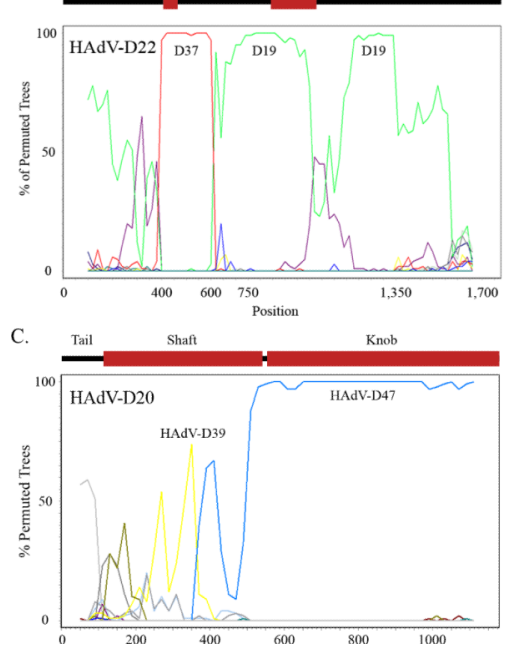

B. Loop 1(HVR 1-6) $\begin{array}{r}\text { Loop } 2 \\ (\text { HVR } 7)\end{array}$
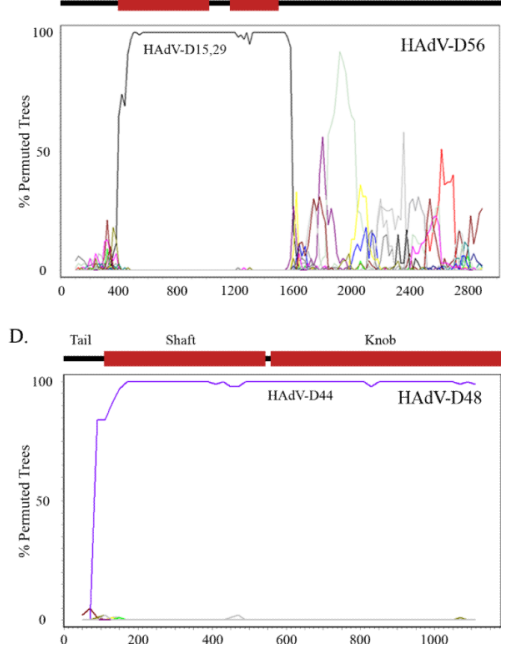

Figure 4.

Recombination analysis of HAdVs. (A) Bootscan analysis of the HAdV-D22 penton base gene. Adapted from (Robinson et al., 2009a). (B) Bootscan analysis of the HAdV-D56 hexon gene. Adapted from (Robinson et al., 2011). (C) Bootscan analysis of the HAdV-D20 fiber gene. (D) Bootscan analysis of the HAdV-D48 fiber gene. 


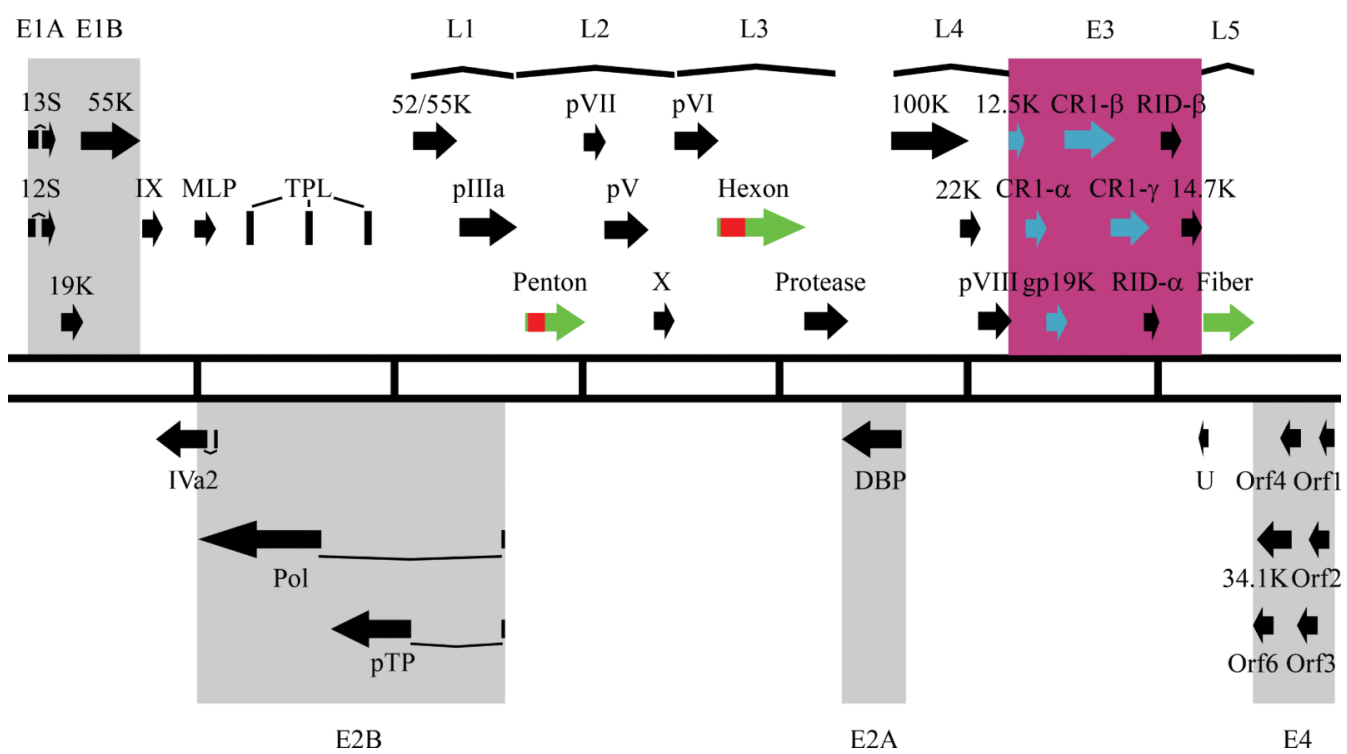

Figure 5.

Recombination and diversity in HAdV-D. Transcriptional map of HAdV-D genomes. Black arrows and blue arrows represent conserved and non-conserved genes across all HAdV species, respectively. Genes identified as recombinant are denoted in green. Recombination hot spots are denoted in red. Pink represents area of major diversity in HAdV genomes. 


\section{Table 1}

Initial sites of isolation of previously identified human adenoviruses.

\begin{tabular}{|c|c|}
\hline Clinical Sites & HAdV types involved \\
\hline Upper respiratory tract & A: $18 \mathbf{B}: 3,7,11,14,16,21 \mathbf{C}: 1,2,5^{\S}, 6 \mathbf{D}: 15,19^{*}, 29,30,37^{*} \mathbf{E}: 4$ \\
\hline Lower respiratory tract & A: 12 B: $3,7,11,14,21,35,55 \mathbf{C :} 1,2,5^{\S} \mathbf{D}: 8^{*}, 19^{*}, 39,56 \mathbf{E}: 4$ \\
\hline Ocular surface & B: $3,7,11,14,16 \mathbf{C :} 2,5^{\S}, 6 \mathbf{D}: 8^{*}, 10,15,17,19^{*}, 22,23,24,37^{*}, 53^{*}, 54,56 \mathbf{E}: 4$ \\
\hline Genitourinary tract & B: $7,11,21,34,35 \mathbf{C}: 1 \mathbf{D}: 8^{*}, 37^{*} \mathbf{E}: 4$ \\
\hline GI tract & $\begin{array}{l}\text { A: } 12,18,31^{\S} \mathbf{B}: 3,7,50^{\S} \mathbf{C}: 2 \mathbf{D}: 9,13,20,25,26,27,28,32,33,36,38,39,42,43^{\S}, 44^{\S}, 45^{\S}, 46^{\S}, 47^{\S}, 48^{\S}, 49^{\S} \text {, } \\
51^{\S} \mathbf{F}: 40,41 \mathbf{G}: 52\end{array}$ \\
\hline Heart & C: $2,5^{\S}, 6$ \\
\hline
\end{tabular}

